\title{
Role of Commerce Education on Growing India's Economy
}

\section{OPEN ACCESS}

Manuscript ID:

EDU-2021-09023667

Volume: 9

Issue: 2

Month: March

Year: 2021

P-ISSN: 2320-2653

E-ISSN: 2582-1334

Received: 03.01.2021

Accepted: 11.02.2021

Published: 01.03.2021

Citation:

Tabasum, Heena, and

S. Venkatesh. "Role of Commerce Education on Growing India's Economy." Shanlax International Journal of Education, vol. 9, no. 2, 2021, pp. 127-131.

DOI:

https://doi.org/10.34293/ education.v9i2.3667

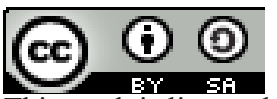

This work is licensed under a Creative Commons Attribution-ShareAlike 4.0 International License

\section{Heena Tabasum}

Research Scholar, Department of PG Studies and Research in Commerce

Kvempu University, Shimoga District, Karnataka, India

\author{
Dr. S. Venkatesh \\ Professor and Chairman, Department of PG Studies and Research in Commerce \\ Kvempu University, Shimoga District, Karnataka, India
}

\begin{abstract}
Commerce education plays a very important role in economic growth. It is one of the keys which lead to success in all sectors of the economy. Commerce education has gained such importance because activities relating to commerce are also affected when the business cycle is going well. Through commerce education, students are exposed to the environment of the business world. It enables the importance of smearing economic ideologies while making business decisions. It makes them aware of social, economic, and political problems. Commerce outfits to the distribution trait of any business. Production must be consumed; there exists a suitable distribution channel to aid this consumption. And that is what commerce does by creating a market for surplus products. It has widened up the global market and has been similarly useful in hastening the practice of exchange in local markets around the globe. It is already established that good commerce plays a tremendous role in the economic development of the country. An attempt is made to analyze the role of commerce education in the growing economy of India.
\end{abstract}

Keywords: Commerce education, Indian economy, Growth, Role, Professionals, Perception.

\section{Introduction}

Commerce education is the backbone of the business and development of the nation. Commerce education shields a wide zone of business and society. It imparts skill-oriented learning to students. Fredrick G. Nicholas described commerce education as a type of training which will play its parts in the achievement of the general aim of education on any given levels has for its primary objectives, the preparation of people to enter the business career or entered upon such career to render more effective service thereon and to advance from their present levels of employment to higher levels. Every business has to perform Commerce as it is an activity to do. Commerce means buying and selling of goods on a large scale in short. Commerce is a composite study of accounts, economics, and business studies. These are the 3 pillars on which commerce stands. Without commerce, there is no business. Commerce provides direction, stability in the organization, and most importantly, it provides growth to the organization. Accounts help the organization to see the true picture or condition of our business with the help of balance sheets, journals, ledgers, etc. Economics, one of the most important aspects of commerce, provides business knowledge on how to use limited resources for business and get a maximum profit in the short term. Business studies provide knowledge about sales management, HR management, marketing, etc. That's why without commerce, there is no business. Commerce is part of all the activities carried out in business, such as planning, advertising, manufacturing, etc. Sometimes business \& commerce seem to be same, but it was different at some angle. 
Business refers to economic activity to generate profit. Commerce is aiding to business. It means commerce involves the activities which are done to facilitate the business. Both commerce and business are profitable activities. Commerce education plays a very important role in economic growth. It is one of the keys which lead to success in all sectors of the economy. Commerce education has gained such importance because activities relating to commerce are also affected when the business cycle is going well. Through commerce education, students are exposed to the environment of the business world. It enables the importance of smearing economic ideologies while making business decisions. It makes them aware of social, economic, and political problems - commerce outfits to the distribution trait of any business. Production must be consumed; there exists a suitable distribution channel to aid this consumption. And that is what commerce does by creating a market for surplus products. It has widened up the global market and has been similarly useful in hastening the practice of exchange in local markets around the globe. It is already established that good commerce plays a tremendous role in the economic development of the country.

\section{Literature Review}

Pratap et al., (2015) highlighted that through commerce education; students are exposed to the outside environment of the business to the world. It also gives them guidance for them in applying principles while doing business. Commerce education gives them confidence and a positive attitude. They also mention that commerce graduates have a lack of practical knowledge. It ensures better management of its resources; they also understand the concept of savings, investment, and capital formation.

Deswa (2017) opines that nowadays, commerce education is taking a professional approach. Commerce education has been changed due to industrial and economic advancements. The change in technology provides a new dimension and reduces the paperwork. They also highlight more on the education system. Any exchange of money, any transaction that happens, all relate to commerce. However, there is no business without commerce.
Mankar (2016) states that today's employment opportunities depend upon qualitative commerce education. Nowadays businesses are changing technology, so skills and training are required to cope up with these changes. In this article, they mention that commerce education has been developed, and now it becomes a business education. Commerce education is just a type of training having the objective of preparing students to enter a business career. The Commerce stream is good for options for the future.

Savalia (2014) highlighted that providing commerce education right from the schools. Other than commerce, in science and arts, we can see different specialized courses but in commerce, we can see only accounting and taxation. Many students are unfamiliar with their specialized fields. As the market is growing vast, there is a need for human resources with efficient commerce knowledge who could deal with all matters of business.

\section{Objectives}

- To analyze the role of commerce education in economic activities to achieve inclusive growth;

- To highlight the role of commerce education in changing the business world;

- To give suitable suggestions based on the findings of the study.

\section{Hypothesis}

\section{Perception towards Commerce Education}

H0: Opinion of Professionals regarding statements on Commerce Education is equal to Average level

H1: Opinion of Professionals regarding statements on Commerce Education is not equal to Average level

\section{Role of Commerce Education on Growing Indian Economy}

H0: Level of Perception of Professionals on Role of Commerce Education on Growing Indian Economy is equally distributed

H1: Level of Perception of Professionals on Role of Commerce Education on Growing Indian Economy is not equally distributed 


\section{Statement of the Problem}

Commerce education is facing numerous problems like Global competition in the market, creating problems for commerce graduates. They are not getting qualitative education, and there is a lack of infrastructure facilities like, well- equipped classrooms with modern communication devices like a computer network, projectors, etc. Theory oriented like syllabus adopted in UG and PG is more theoretical and lacks practical knowledge. In India, most commerce education institutions are dependent on government grants and government grants are insufficient to provide good infrastructure and learning resources, which are a must to provide world-class knowledge to students. Only general education is providing in the name of commerce education, which is not effective. Many of them are failing to recognize the opportunities that are available for the commerce stream. Commerce education lacks employability skills and does not make the students face the complexities in business. Many of them are unable to make decisions; they think that commerce is not best for their career option so that they are moving towards engineering, medicine, IT courses. It is very sad to say that students from arts and science backgrounds who do not have basic business and commerce knowledge are grabbing the opportunities of commerce students. At the school level, there is no basic subject related to commerce, just like we have in the science and arts stream. Lack of technological skills in the students who are very important for the future. Because of these problems, commerce is not gaining importance like any other stream.

\section{Research Methodology}

The data required for the study has been collected from primary sources by distributing the questionnaire to sample respondents who are the professional in the field of commerce and a total number of 150 respondents selected by using convenient sampling. The collected data analyzed by using SPSS software by applying the chi-square test, t-test, mean and standard deviation.

\section{Data Analysis And Interpretation Hypothesis Testing \\ Hypothesis I}

Null Hypothesis: Opinion of Professionals regarding statements on Commerce Education are equal to Average level.

Table 1: t-test for Specified Value (Average=3) of Statements on Commerce Education Perception of Professionals

\begin{tabular}{|l|c|c|c|c|}
\hline \multicolumn{1}{|c|}{ Statements on Commerce Education Perception } & Mean & SD & t value & P value \\
\hline It helps to transfer human being into human resources & 3.90 & 1.07 & 16.776 & $<0.001^{* *}$ \\
\hline Creates many opportunities for future growth & 4.10 & 1.03 & 21.291 & $<0.001^{* *}$ \\
\hline Increases the skills and knowledge & 3.99 & 1.14 & 17.472 & $<0.001^{* *}$ \\
\hline It contributes for industrial development and growth of India & 3.90 & 1.21 & 14.878 & $<0.001^{* *}$ \\
\hline
\end{tabular}

Note: ${ }^{* *}$ denotes significance at $1 \%$ level

Since P-value is less than 0.01 , the null hypothesis is rejected at a $1 \%$ level of significance about all the statements on Commerce Education opinion of Professionals. Hence the opinion regard to all the statements on Commerce Education of Professionals is not equal to average level. Based on the mean score, opinion regarding all the statements onCommerce Education of Professionals are above average level. This shows that Commerce education certainly helps transform human beings into human resources by imparting skills and knowledge. It creates opportunities for growth by way of contributing to the industrial development and growth of India. This is because commerce is needed in all sectors to do their work effectively and efficiently. This, in turn, leads to high demand for the stream.

\section{Hypothesis II}

Null Hypothesis: Level of Perception of Professionals on Role of Commerce Education on Growing Indian Economy is equally distributed 
Table 2: Chi-square test for Goodness of Fit of Equality of Level of Perception of Professionals on Role of Commerce Education on Growing Indian Economy

\begin{tabular}{|c|c|c|c|c|}
\hline $\begin{array}{c}\text { Level of } \\
\text { Perception } \\
\text { on Role of } \\
\text { Commerce } \\
\text { Education }\end{array}$ & Frequency & \% & $\begin{array}{c}\text { Chi- } \\
\text { square } \\
\text { Value }\end{array}$ & P value \\
\hline Low & 3.90 & 25.5 & & \\
\hline Moderate & 4.10 & 49.0 & \multirow{2}{*}{44.180} & $<0.001^{* *}$ \\
\hline High & 3.99 & 25.5 & & \\
\hline Total & $\mathbf{3 . 9 0}$ & $\mathbf{1 0 0 . 0}$ & & \\
\hline
\end{tabular}

Note: $* *$ denotes significance at $1 \%$ level

Since P-value is less than 0.01 , the null hypothesis is rejected at $1 \%$ level of significance. Hence concluded that the level of Perception of Professionals on the Role of Commerce Education in the Growing Indian Economy is not equally distributed. Based on percentage, the majority of professionals belong to the Moderate level (49.0\%). As few professional opine, that role of commerce education on growing Indian economy is low due to less job placement and more output, where few opinions moderate because a large number of contribution done by commerce output in the field of production and consumption, where few opine that the role of commerce education is high and contributes in growing India's economy.

\section{Findings}

- It is found that commerce education plays an important role in contributing to Indian economy growth by providing opportunity in the field of business, production and consumption.

- It is also found that, commerce education is vital but placement is quite low due to huge output.

\section{Suggestions}

To improve the infrastructure and learning resources of commerce education to meet global challenges facilities such as communication devices like computer networks, internet facilities, business labs, overhead projectors, etc.

One of the important suggestions for commerce education is, it should provide not only theoretical oriented knowledge but also practical knowledge so they can easily face the competitive world.
While constructing the syllabus, it is better to consult industrialists from various fields which is more relevant, Contextual, and industry-oriented.

\section{Conclusion}

India has the strategic advantage of the young population. Under the WTO regime, the relevance of management education has become more imperative; this means marked changes in the way commerce and management education is perceived in India. Therefore, it is inevitable to make commerce graduation courses more impactful. Commerce education is facing numerous problems nowadays. These problems have a direct bearing on the course objectives, course contents. Therefore there is a need for an effort to re-designing commerce education in such a way that it should be relevant to today and tomorrow. Globalization has provided a scope of opportunities to our commerce undergraduates and postgraduates and expecting the providing the challenges to our commerce education of equipping our students with multiple skills to meet the expectations of the global job market all over the globe. Nowadays, commerce education has become the backbone of every country's economic system. The demand is strong in India and worldwide for graduates who develop the potential to take leadership roles in international business. Surely, India will excel in talent management and knowledge management shortly if the government puts its hand together with the higher education sector for providing quality education to the students. By making relevant and practical oriented commerce education, it may be impacted global competitiveness to our students. Hence the role of Commerce Education in national development is well established.

\section{References}

Agarwal, Pawan, Indian Higher Education: Envisioning the Future. Sage, 2009.

Aggarwal, J.C. Teaching of Commerce: A Practical Approach. Vikas Publishing, 1996.

Ahirrao, Jitendra, and Prakash Ratanlal Rodiya. "Emerging Trends in Commerce Education to Face the Challenges of Dynamic Business World." Indian Streams Research Journal, vol. 2, no. 6, 2012. 
Ahmad, Mushtaque. Business Education - Retrospect and Prospects, 2004.

Bansal, Rohit. "Challenges and Future Trends in Commerce Education in India." International Journal of Techno-Management Research, vol. 5, no. 3, 2017, pp. 15-25.

Chakraborty, Prithul. "Commerce Education in the Changing Business Scenario in India: Challenges and Opportunities." Vidyasagar University Journal of Commerce, vol. 15, 2010, pp. 22-30.

Chattopadhya, P. "Commerce Education." Commerce Education in India, edited by Devadas Bhorali, Deep \& Deep Publications, 1987.

Deswal, Vijay. "Challenges and Opportunities in Commerce Education in India." International Journal of Advanced Research and Development, vol. 2, no. 6, 2017, pp. 870-872.

Ghosh, A.B. Commerce Education. Sultan Chand and Sons, 1969.

Higher Education in India - Issues related to Expansion, Inclusiveness, Quality and Finance, UGC, 2008.

Hugar, S.S. Challenges Before Business Education in India. Atlantic Publishers and Distributors, 2001

Khanzode, V.V. Recent Trends in Commerce and Management Education. Strling Publishers Pvt Limited, 1990.

Khawas, S.G. "Challenges and Opportunities in Job Oriented Commerce Education." Global Economic Research, vol. 1, no. 1, 2011.
Mahajan, K.A., and Meiraj-uddin-Shah. "Service Quality in Business Education." India Journal of Commerce, vol. 59, no. 3, 2006.

Mahto, A.K., and S.K. Jha. "Need to Relook Commerce Education in India." Paripex Indian Journal of Research, vol. 3, no. 5, 2014, pp. 143-146.

Mankar, Deepali Kailasrao. "Importance of Commerce Education in India." International Educational Scientific Research Journal, vol. 2, no. 7, 2016, pp. 43-44.

Nadaf, Shamshuddin M., and Yasmin Begum R Nadaf. "Commerce Education: Rationale for Study." International Journal of Humanities and Social Science Research, vol. 3, no. 5, 2017, pp. 11-15.

Reddy, Obul. "Revitalising Commerce Education." Vidyasagar University Journal of Commerce, vol. 12, 2007.

Roa, "Teaching of Commerce", Anmol Publication pvt ltd. 1995

Savalia, J.D. "Inclusive Growth and Sustainability - Role of Commerce Education in India." International Journal of Trend in Research and Development, vol. 1, no. 1, 2014.

Singh, Ajay Kumar, and Shilpi Sahi. "Activity Based Learning in Commerce Education: An Empirical Analysis of Preferred Learning Styles and Instruction Approach." Indian Journal of Commerce, vol. 65, no. 2, 2012.

Singh, Partap, et al. "Role of Commerce Education in Inclusive Growth of India." International Journal of Latest Trends in Engineering and Technology, vol. 6, no. 1, 2015, pp. 311-320.

\section{Author Details}

Heena Tabasum, Research Scholar, Department of PG Studies and Research in Commerce, Kvempu University, Shimoga District, Karnataka, India, Email ID: heenatke@gmail.com

Dr. S. Venkatesh, Professor and Chairman, Department of PG Studies and Research in Commerce, Kvempu University, Shimoga District, Karnataka, India. 